ARTICLE

\title{
The roles of attitudes towards learning and opposite sex as a predictor of school engagement: mixed or single gender education?
}

\author{
Mustafa Yüksel Erdoğdu (iD ${ }^{1 凶}$
}

\begin{abstract}
Students' attitudes towards learning and their school engagement play important roles on the success of educational programs. Therefore, the main purpose of this research is to examine the roles of attitude towards learning and attitude towards the opposite sex as a predictor of school engagement and to determine the correlation between mixed gender education vs. single gender education and school engagement. Eight hundred and forty-three students (525 females and 318 males) who were studying in single gender or mixed gender schools were included in the research. Data were collected through School Engagement Scale, Attitude Scale towards Learning and Opposite Sex Attitude Scale. The Pearson moment correlation coefficient, multiple regression and stepwise regression were used to analyze the data. Findings showed that attitudes towards learning scores are the most predictive for school engagement. Results also showed that school engagement was higher in single gender schools for girls than in single gender schools for boys and mixed gender schools. The success of the student and the attitude towards the opposite sex were also variables that predict school engagement. The democratic attitude and education levels of parents also had important effects on students' school engagement. The findings have important implications for educational policy making and curriculum designs. Some general recommendations were made based on the findings.
\end{abstract}

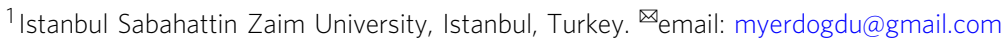




\section{Introduction}

he development of societies is possible with the presence of trained and equipped manpower. Undoubtedly, the important impact of the school cannot be ignored in the training of qualified manpower required by the modern times. The school not only is an environment that provides students with academic knowledge and improve their mental processes, but also bears features that affect their emotional, social, physical, and moral development. Hence, it is important for children to have positive feelings towards school so that they can benefit from the educational activities at the highest level. There are many factors originating from individual and family that affect students' attitudes towards the school. One of them is school engagement.

There have been many definitions of school engagement to date. While Silins Mulford (2002) defined school engagement as going to school regularly, participating in school-related decisions and social activities, Finn (1993) described it as feeling the sense of belonging to the school and adopting school's objectives. The common ground in school engagement is that students identify themselves with the school and participate in school-related activities (Audas and Willms, 2002; Finn and Voelkl, 1993). In this context, school engagement in general can be defined as how the individual embraces the school, integrates themselves with school's objectives, participates in cultural and social activities in the school and wants to be together with their friends and teachers.

School engagement is addressed in affective, cognitive, and behavioral dimensions. Cognitive dimension refers to students' willingness to learn, their positive attitude towards learning; behavioral dimension is about students' participation in sporting and cultural activities; and emotional dimension is described as students' having a positive attitude towards school and friends at school (Finlay, 2006; Fredricks et al., 2004). It has been observed that students with high school engagement go to school more frequently, are less absent from school and have lower dropout rates (Connell et al., 1994; Hirschfield and Gasper, 2011; Janosz et al., 2008; McNeely and Falci, 2004). Furthermore, research results have explored that students with high school engagement levels are also those who are academically successful (Appleton et al., 2006; Hirschfield and Gasper, 2011; Klem and Connell, 2004; Simons-Morton and Chen, 2009).

Studies on school engagement in the literature seem to address many different variables. In the study conducted by Erdoğdu (2016), friendship relations predicted school engagement on a higher level than teacher attitudes, and school engagement of those who attended cultural and sporting activities was on higher levels. Shin et al. (2007) achieved similar results and explored that peer support had a positive effect on school engagement. Thaliah and Hashim (2008) reported that students' school engagement levels were higher when they had more teacher support. Arastaman (2009) and Conchas (2001) found that children of parents with low socio-economic status experienced more school engagement.

There are several variables that affect students' school engagement, and one of them is the attitude towards learning. The concept of learning has been defined in many different ways. According to some scientists, learning is a relatively permanent change in behavior resulting from experiences in the interaction with environment (Hergenhann, 1988; Hoy and Miskel, 2010; Schunk, 2009). Whereas behaviorists describe learning as only observable behavioral changes since they ignore internal processes (Schwartz and Reisberg, 1991), cognitive theorists focus on mental processes and state that there is no need for observable behavior to occur in learning. Ormrod (1990) defines the concept of learning as the association of new knowledge with existing knowledge based on the knowledge-processing approach. Positive attitudes towards learning affect the learning of individuals both in school and real life. In the case of positive attitudes towards learning, it is observed that individuals perform more successfully in academic terms (Bråten and Strømsø, 2006; Duarte, 2007) and that emotions and thoughts about learning affect student behaviors (Pierce et al., 2007). Prokop et al. (2007) showed that there was a positive correlation between the level of knowledge and individuals' positive emotions towards learning. A study by Aktürk (2012) concluded a positive relationship between the preservice teachers' positive attitudes towards learning and their academic achievement. Erdoğdu (2017), observed that the students with a positive attitude towards learning were more successful, had higher motivation for the courses, participated more in cultural activities in the school and listened to the teacher in the class more carefully.

One of the variables which is assumed to relate to school engagement is students' opposite-sex attitudes; that is the relationship between opposite-sex attitude and school engagement (Liem and Martin, 2011). Opposite-sex attitude refers to emotional tendencies against opposite sex. These tendencies shape sexes' behaviors towards each other cognitively, behaviorally and affectively. Formation of opposite-sex friendships, which can be defined as the desire of two different sexes to coexist with each other, purpose of this coexistence, and the way it is realized vary by developmental processes. During the developmental period between the ages of 3 and 6, also called early childhood, oppositesex friendships are observed in plays whereas in late childhood which refers to 7-11 years of age such friendships is observed in activities of learning, investigating and being successful In adolescence, opposite-sex friendship might result in emotional coexistence and marriage.

According to the psychoanalytic theory, efforts to develop intimacy with the parent of the same sex in the phallic era tend to shift towards the opposite-sex parent in the latent period (Öztürk, 1995), and immediately afterwards, opposite-sex friendships gain importance in the genital period. Sullivan (1953) argues that efforts to establish friendship with the opposite sex increase further during adolescence, and these efforts of becoming intimate happen to be the developmental task of this period. Purposes of establishing friendship with the opposite sex may differ by gender. In the study conducted by Lacey et al. (2004), the preference of the women in opposite-sex friendships was the social status and income of men whereas the men attached more importance to the physical attractiveness of women. Another study by Underwood et al. (2009) reported that the adolescent girls expected to become only friends with boys while the boys were in the expectation of an emotional relationship. Adolescents can learn their self, gender-based identity and role by befriending the opposite sex. In this context, positive attitudes towards the opposite sex are important for them, since they help them acquire their developmental characteristics (Collins and Sprinthall, 1995). Studies on opposite-sex friendship in Turkey seem to address the relationship between opposite-sex friendship and social selfefficacy (Başaranoğlu, 2011; Türkoğlu et al., 2015), but there has been no study performed on the relationship between attitude towards opposite-sex friendship and academic achievement at school.

Of research interest is whether school engagement differed by attending a coed or single-sex school. Coeducation can be described as female and male students' receiving education in the same environment while single-sex education refers to how only students of the same sex receive education in the same environment (Hammaker, 1995; Mael, 1998). Not only in Turkey but also around the world, the effects of coeducation or single-sex education on the development of individuals have still been 
investigated (Gibb et al., 2008; McFarland et al., 2011; Rycik, 2008; Schober et al., 2004). Debates on coeducation arose for the first time after the foundation of the republic in Turkey when girls wanted to enroll in boy high schools in Tekirdağ (Kamer, 2013). The implications of coeducation or single-sex education are the matter of concern not only in education policies but also in political and ideological debates. There are those who argue that coeducation is more effective as it increases respect among opposite sexes, improve their confidences and make them study together while others advocate the idea that singlesex education is more effective because coeducation leads to moral degeneration.

At the US congress, Hillary Clinton (2001) said, “There should be no obstacles to single-sex education in the education system of the state. We have to see the successes of single-sex schools. These schools encourage students and parents", emphasizing the effectiveness of single-sex education. Some studies show that female students studying in single-sex classes are more successful than in co-educational schools (Kohlhaas et al., 2010; McFarland et al., 2011; Mulholland et al., 2004). Thom (2006) achieved similar results in another research. According to Leonard (2007), this is because such schools are more careful about choosing students.

Moreover, some studies have shown that academic achievements of schools significantly differ by being a coed or single-sex school (Fritz, 1997; Garcia, 1998; Schober et al., 2004; Scoggins, 2009; Spielhofer et al., 2004). There are also research findings indicating that coeducation yields more positive results than single-sex education setting in terms of academic education (Elam, 2009; Marsh and Rowe, 1996). As abovementioned, previous research studies achieved different findings on whether coed or single-sex schools increase academic achievement more. In Turkey, to the best of the researcher knowledge, no research has been conducted on the relationship between coed or singlesex education and academic achievement.

This study aims to make contributions to the literature by testing the effects of variables which are assumed to be related to school engagement with regression analysis. It is anticipated that the research findings will guide future studies on increasing students' school engagement. In the light of discussion made above study examined, the questions to be addressed in this study are: (1) is there a relationship between school engagement, attitude towards learning, opposite-sex attitude, type of school, parental attitude, and parents' educational level? (2) is there a relationship between school engagement and achievement level? (3) to what extent does type of school, achievement level, parental attitude, and parents' educational level predict school engagement?

\section{Method}

Research model. This research was carried out in the relational survey model since it aimed to determine how the variables that are assumed to relate to school engagement predict the level of school engagement. According to Heppner et al. (2013), research aiming to explore the relationship(s) between two or more variables is called relational research.

Study group. As the research was performed on coed and singlesex schools, stratified purposive sampling method of purposive sampling methods was used to choose the schools. In this method, the sample is composed of subgroups of interest to show, describe, and compare their characteristics. It is also called quota sampling (Büyüköztürk et al., 2012). The research was conducted on the students attending girls', boys', and coed high schools within the boundaries of Istanbul Metropolitan Municipality. Table 1 shows the number of girls and boys attending the schools that were selected for the research sample.

\begin{tabular}{|c|c|c|c|}
\hline Schools & Girl & Boy & Total \\
\hline Girls' vocational high school & 316 & - & 316 \\
\hline Boys' high school & - & 154 & 154 \\
\hline Private (coed) & 100 & 65 & 165 \\
\hline Public (coed) & 109 & 99 & 208 \\
\hline Total & 525 & 318 & 843 \\
\hline
\end{tabular}

Participants were 525 (62.3\%) girls and 318 (37.7\%) boys. Instruments were applied to 316 (37\%) students from girls' vocational high schools, 154 (19\%) students from boys' high schools and 373 (44\%) students from coed high schools (843 volunteered students in total).

Of the total students who participated in the study, 264 (31\%) perceived themselves as successful, 531 (63\%) as moderately successful, and $48(6 \%)$ as unsuccessful. The students reported that their parents had authoritarian attitude (93 [11\%]), democratic attitude (163 [19\%]), over-protective attitude (366 [43\%]), over-demanding attitude (136 [16\%]) and other parental attitudes $(79[10 \%])$. As for education levels of the students' mothers, $35(4 \%)$ are illiterate, $306(36 \%)$ are primary school graduates, $351(42 \%)$ are high school graduates and 147 (17) are university graduates. Of their fathers, $10(1 \%)$ are illiterate, 243 (29\%) are primary school graduates, 377 (45\%) are high school graduates and $208(25 \%)$ are university graduates.

\section{Data collection instruments}

School Engagement Questionnaire (SEQ) (Arastaman, 2006). The SEQ developed by Arastaman is graded on a 5-point Likert scale. The instrument consists of 9 items and 5 factors. The subscales are Student's Internal Engagement, School Environment Engagement, School Program Engagement, School Administration's Engagement Relationship, Teacher's Engagement Relationship. Cronbach's Alphas of the subscales vary between 0.65 and 0.83 . The variances explained by the subscales were calculated to be between $7.94 \%$ and $14.72 \%$ (Arastaman, 2006). Since all items provided a total score on school engagement, the subscales were not used in this study. In this current study, the Cronbach's Alphas of all items were recalculated, and the reliability value was found to be 0.95 .

Scale of Attitudes Towards Learning (SATL) (Kara, 2010). The SATL was applied to determine students' attitudes towards learning. The scale consists of 4 factors which are Nature of Learning (7 items), Expectation (9 items), Openness (11 items), and Anxiety (13 items). Cronbach's Alphas of the subscales range from 0.72 to 0.78 . The factor analysis concluded the factor loadings of the scale to be within acceptable limits. Test-retest reliability coefficient of the scale was calculated to be 0.87 . For this study, the Cronbach's Alpha of the scale was recalculated, and the reliability value was 85 .

Opposite-Sex Attitude Scale (OSAS) (Erdo $\breve{g} d u, 2018)$. The OSAS is a 26-item 5-point Likert scale. An exploratory factor analysis was performed for the validity study, and all 26 items were observed to group under a single great factor with an eigenvalue $>1$. The variance explained by this single factor is $53.13 \%$. Common variances of the single factor vary between 0.321 and 0.614 . KMO values, Bartlett's Test, and Cronbach's Alpha internal consistency coefficients of the final version of the scale were calculated, and the obtained data were found within acceptable limits. The Cronbach's Alpha of the scale was calculated to be 0.95 for the 
reliability study. Item discriminations were calculated to support the construct validity, and each item's discriminants were found to be significant. The Cronbach's Alpha of the scale was recalculated, and the reliability value was found to be 0.96 .

An information form was prepared by the researcher to obtain students' demographic data.

Procedure and data analysis. Consent letters were obtained from the volunteer students and their parents and the required permissions were also obtained from the school authorities where the study was conducted, and the instruments were applied to volunteered students in groups in the classroom setting.

The relationships between predictor variables and predicted variables were calculated with Pearson's product moment correlation coefficient. In the research, the categorical variables were converted to dummy variables produced in the amount that is one minus the number of levels by excluding one of the levels. Next, a multiple regression analysis was performed to determine to what extent the independent variables converted to dummy variables predicted the dependent variable. Then, a stepwise regression analysis was carried out to determine which of the independent variables contributed significantly to the prediction of school engagement level. How each of these independent variables contributed to the variance when predicting school engagement were also calculated.

\section{Results}

Descriptive statistics of the instruments used in the research are given in Table 2.

As shown in Table 2, the mean score was 100.87 and the standard deviation was 17.72 for the SEQ, the mean score was 93.35 and the standard deviation was 21.20 for the OSAS, and the mean score was 146.40 and the standard deviation was 16.78 for the SATL.

The correlation coefficients among the variables addressed in the study are given in Table 3 .

As shown in Table 3, a moderate positive correlation was found between the scores of SEQ and Scale of Attitudes toward Learning $(r=0.486, p<0.01)$. There was no significant correlation between the scores of SEQ and Scale of Attitude towards Learning ( $r=$ $-0.028, p>0.01)$. A positive correlation was observed between the achievement levels and the scores of SEQ $(r=0.236, p<0.01)$. There were low, negative, significant correlations between the scores of SEQ and mother's education level $(r=-0.154, p<0.01)$ and father's education level $(r=-0.185, p<0.01)$. A low, negative, significant correlation was found between the scores of SEQ and the type of school $(r=-0.335, p<0.01)$. No significant correlation was observed between the scores of SEQ and the perceived parental attitudes $(r=-0.056, p>0.01)$.

Since the students' demographics were categorical variables, these variables were converted to dummy variables before the analysis, and a multiple regression analysis was carried out to determine to what extent each of these categorical variables predicted school engagement. The findings are presented in Table 4.

\begin{tabular}{|c|c|c|c|c|}
\hline Instruments & Items & $\bar{X} \pm S$ & Min. & Max. \\
\hline $\begin{array}{l}\text { School Engagement } \\
\text { Questionnaire }\end{array}$ & 27 & $100.87 \pm 17.72$ & 29 & 135 \\
\hline Opposite-Sex Attitude Scale & 26 & $93.35 \pm 21.20$ & 26 & 130 \\
\hline $\begin{array}{l}\text { Scale of Attitudes Towards } \\
\text { Learning Scale }\end{array}$ & 40 & $146.40 \pm 16.78$ & 70 & 187 \\
\hline
\end{tabular}

The scores obtained by the students attending different types of school (Boys' High School, Girls' High School, Coed High School) significantly predicted students' school engagement $(R=0.342$, $\left.R^{2}=0.117, p<0.001\right)$. These three variables explained $12 \%$ of the variance on the level of school engagement. According to the standardized regression coefficient $(\beta)$, the relative order of significance of the predictor variables for school engagement is the scores obtained by girls' high school, boys' high school and coed high school students, respectively. There was a negative correlation between the scores obtained by the boys' high school students and their school engagement scores. As for the $t$-test results regarding the significance of the regression coefficients, the scores obtained by the boys' high school and girls' high school students were found to be significant predictors of school engagement.

The scores obtained by the students with different achievement levels (successful, moderately successful, unsuccessful) predicted their school engagement $\left(R=0.261, R^{2}=0.068, p<0.001\right)$. These three variables explained $7 \%$ of the variance on the level of school engagement. According to the standardized regression coefficient $(\beta)$, the relative order of significance of the predictor variables for school engagement is the scores obtained by the unsuccessful, successful and moderately successful students, respectively. There was a negative correlation between the scores of the unsuccessful students and their school engagement scores. Given the $t$-test results concerning the significance of the regression coefficients, the scores obtained only by the successful and unsuccessful students significantly predicted school engagement.

The scores obtained by the students with different perceived parental attitudes (democratic, over-protective, authoritarian, over-demanding) significantly predicted students' school engagement $\left(R=0.145, R^{2}=0.021, p<0.001\right)$. These four variables explained only $2 \%$ of the variance on the level of school engagement. According to the standardized regression coefficient $(\beta)$, the relative order of significance of the predictor variables for school engagement is the scores obtained by the students who had parents with democratic, over-protective, over-demanding, and authoritarian attitudes, respectively. In regard to the $t$-test results concerning the significance of the regression coefficients, the scores obtained by the students who had parents with democratic and over-protective attitudes were found to be significant predictors of school engagement.

The scores obtained by the students whose mothers have different educational levels (illiterate, primary school, secondary education, university) significantly predicted students' school engagement $\left(R=0.165, R^{2}=0.027, p<0.001\right)$. However, no significant correlation was observed between the scores of the students whose mothers have different educational levels and their school engagement scores.

The scores obtained by the students whose fathers have different educational levels (illiterate, primary school, secondary education, university) significantly predicted students' school engagement $\left(R=0.228, R^{2}=0.052, p<0.001\right)$. These four variables explained only $5 \%$ of the variance on the level of school engagement. According to the standardized regression coefficient $(\beta)$, the relative order of significance of the predictor variables for school engagement is the scores obtained by the students whose fathers are primary school graduates, secondary education graduates, university graduates, and illiterate, respectively. As for the $t$-test results regarding the significance of the regression coefficients, the scores obtained only by the students whose fathers are primary school and secondary school graduates were found to be significant predictors of school engagement.

Stepwise regression analysis of the predictors of students' school engagement levels is shown in Table 5.

The analysis was completed in seven steps. The variable of attitude towards learning, which explained the greatest variance at 
Table 3 Correlations among the variables in the research.

\begin{tabular}{|c|c|c|c|c|c|c|c|c|}
\hline & 1 & 2 & 3 & 4 & 5 & 6 & 7 & 8 \\
\hline 1. SEQ & - & & & & & & & \\
\hline 2. SATL & $0.486^{\star \star}$ & - & & & & & & \\
\hline 4. Type of school & $-0.335^{\star \star}$ & $-0.081^{\star}$ & $-0.062^{\star}$ & - & & & & \\
\hline 5. Achievement level & $0.236^{\star \star}$ & $0.234^{\star \star}$ & 0.028 & $0.174^{\star \star}$ & - & & & \\
\hline 6. Parental attitude & $-0.056^{\star}$ & $-0.032^{\star}$ & $-0.026^{\star}$ & $-0.086^{\star}$ & $-0.045^{\star}$ & - & & \\
\hline
\end{tabular}

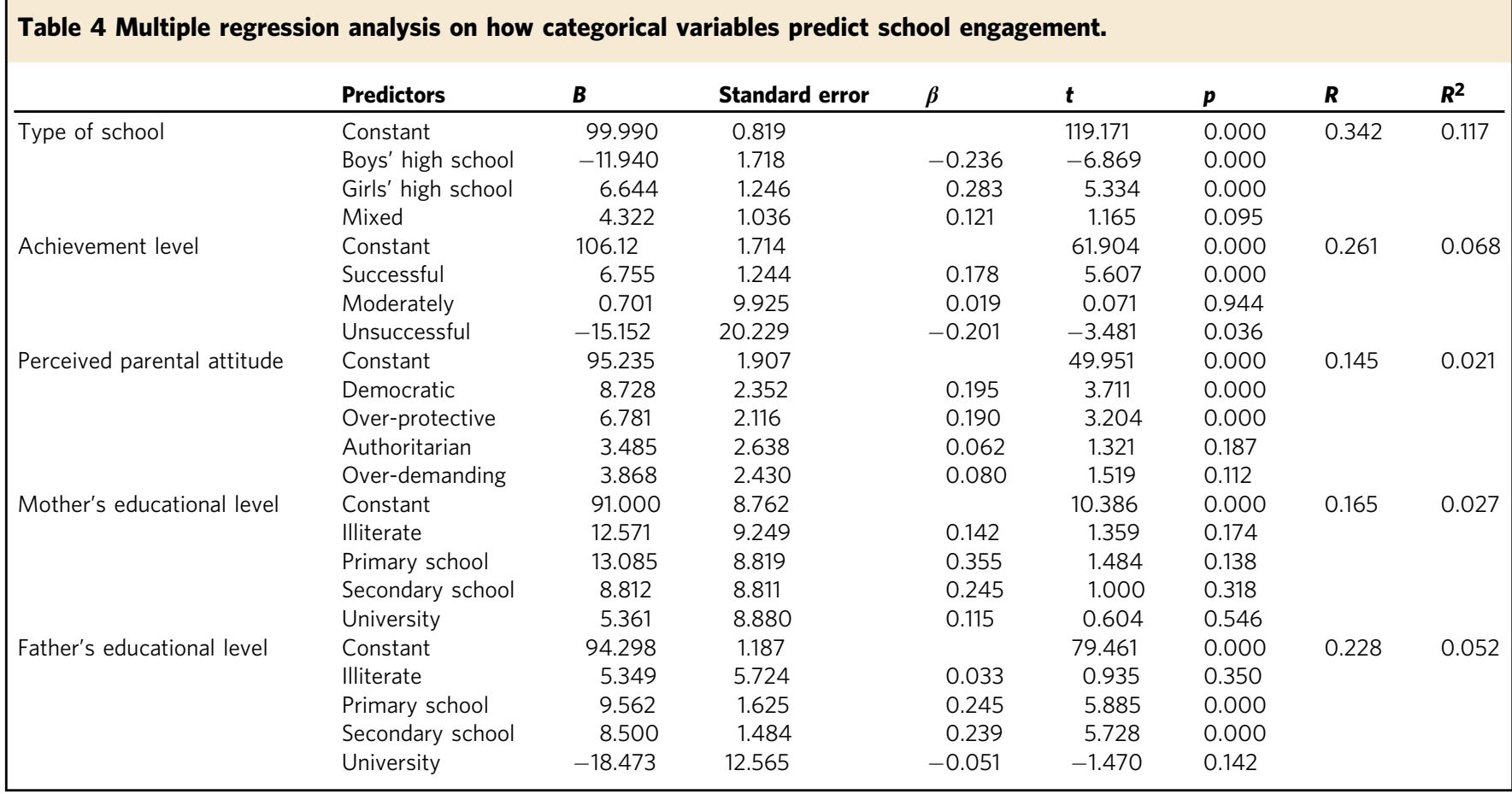

$24 \%$ in the school engagement variable, was included in the first step of the analysis. There was a positive correlation between positive attitudes toward learning and school engagement. With the inclusion of type of school, which had a $7 \%$ contribution to the variance, in the second step, the explained variance increased to $31 \%$. A negative significant correlation was found between attending a coed high school and school engagement. Achievement level, which contributed to the variance at $2 \%$, was included in the third step, and the explained variance increased to $33 \%$. There was a negative significant correlation between students' perceiving themselves as unsuccessful and school engagement. The boys' high schools were included in the fourth stage of the analysis. Boys' schools contributed $2 \%$ to variance, and the explained variance increased to $35 \%$. There was a negative significant correlation between the scores obtained by boys' high school students and school engagement. Achievement level, which contributed to the variance at $2 \%$, was included in the fifth step again, and the explained variance increased to $37 \%$. There was a positive significant correlation between high achievement levels of the students and their school engagement levels. In the sixth step of the analysis, the opposite-sex attitude scores, with very little contribution of $4 \%$ to the variance, was included, and the explained variance increased to $38 \%$. A low, negative correlation was found between the opposite-sex attitude scores and school engagement. In the last step, primary school graduate fathers were included with $3 \%$ contribution to the variance, and the total explained variance increased to $38 \%$.

\section{Discussion, conclusion and recommendations}

The research results indicate that the scores obtained by girls' high school students predicted the school engagement levels more than boys' high school students and mix-gender school students. While a negative correlation was found between the scores obtained by the boys' high school students and their school engagement scores, there was no significant correlation between the scores obtained by the coed high school students and school engagement. It is thought that the girls had higher levels of school engagement because they interact with each other more in school. They experience problems with going out of house unless they go to school which is due to their conservative family structures. Furthermore, the reason why they had high levels of school engagement could be associated with the fact that they become mature more rapidly than their male peers and are more willing to succeed. Similar results were obtained in several studies (Deem, 1984; Fullarton, 2002; Gauley, 2017; Neel and Fuligni, 2013; Spender and Sarah, 1980), and the girls were found to have lower 


\begin{tabular}{|c|c|c|c|c|c|c|c|c|}
\hline Model & Predictors & B & Standard error & Beta & $t$ & $\boldsymbol{R}$ & $R^{2}$ & $\begin{array}{l}R^{2} \text { change } \\
\Delta R^{2}\end{array}$ \\
\hline 1 & Attitudes learning & 0.513 & 0.032 & 0.486 & 16.128 & & & \\
\hline \multirow[t]{2}{*}{2} & Constant & 30.242 & 4.500 & & 6.720 & 0.553 & 0.306 & 0.070 \\
\hline & Attitudes learning & 0.496 & 0.030 & 0.469 & 16.291 & & & \\
\hline \multirow{3}{*}{3} & Attitudes learning & 0.467 & 0.030 & 0.442 & 15.336 & & & \\
\hline & Type of school (mix) & -13.765 & 1.438 & $-0.272^{\star}$ & $-9.59^{\star}$ & & & \\
\hline & Unsuccessful group & -12.163 & 2.291 & $-0.153^{\star}$ & -5.309 & & & \\
\hline \multirow[t]{3}{*}{4} & Constant & 39.650 & 4.523 & & 8.766 & 0.593 & 0.352 & 0.023 \\
\hline & Attitudes learning & 0.458 & 0.030 & 0.434 & 15.288 & & & \\
\hline & Type of school (mix) & -17.032 & 1.532 & $-0.336^{\star}$ & -11.115 & & & \\
\hline \multirow{4}{*}{5} & Type of school (mix) & -18.772 & 1.552 & $-0.370^{\star}$ & -12.099 & & & \\
\hline & Unsuccessful group & -11.055 & 2.238 & $-0.139^{\star}$ & -4.939 & & & \\
\hline & Type of school (boy) & -6.184 & 1.057 & $-0.174^{\star}$ & -5.850 & & & \\
\hline & Successful group & 0.685 & 0.138 & 0.143 & 4.956 & & & \\
\hline \multirow[t]{7}{*}{6} & Constant & 53.032 & 5.287 & & 10.031 & 0.611 & 0.375 & 0.004 \\
\hline & Attitudes learning & 0.429 & .030 & 0.407 & 14.307 & & & \\
\hline & Type of school (mix) & -19.167 & 1.512 & $-0.378^{\star}$ & -12.280 & & & \\
\hline & Unsuccessful group & -10.810 & 2.237 & $-0.136^{\star}$ & -4.832 & & & \\
\hline & Type of school (boy) & -5.958 & 1.060 & $-0.169^{\star}$ & -5.648 & & & \\
\hline & Successful group & 0.695 & 0.138 & 0.146 & 5.036 & & & \\
\hline & Opposite-sex attitude & $-0.047^{\star}$ & 0.023 & $-0.057^{\star}$ & -2.209 & & & \\
\hline \multirow[t]{2}{*}{7} & Constant & 51.871 & 5.308 & & 10.772 & 0.614 & 0.377 & 0.003 \\
\hline & Attitudes learning & 0.432 & 0.030 & 0.409 & 14.403 & & & \\
\hline
\end{tabular}

achievement levels in coed schools (Lee and Bryk, 1986). Nevertheless, there are research findings indicating that there were no significant differences between the coed school students and the achievements of the single-sex school students (Marsh, 1989; Roberson, 2010; Smithers and Robinson, 2006).

As Table 3 shows, there is a positive significant correlation between students' school engagement levels and their achievement level. In other words, the academically more successful students were found to have higher school engagement levels. Enjoying being in school and participating in school activities, certainly, create a sense of belonging and responsibility in students, which therefore leads to higher levels of school engagement. Previous studies showed that the academically successful students had higher levels of school engagement (Erdoğdu, 2016; Finn and Rock, 1997; Fredricks et al., 2004).

The students who perceived their parents' attitudes as democratic and protective against external threats had higher levels of school engagement. The reason for students' higher levels of school engagement could be that their parents respect child's development and decisions, support their decisions and engagement in child's school life and achievements. Research has shown that family participation in the child's school life (Simons-Morton and Crump, 2003) and the presence of family support (Mengi, 2011) contribute to higher school engagement levels among these students. Another study by Finn and Rock (1997) showed that the family structure had a decisive role in school engagement.
While there was no significant correlation between mother's educational level and the students' school engagement levels, the levels of school engagement were higher among the students whose fathers have low educational levels. The reason why higher levels of school engagement were found among the students with parents with low educational levels might be due to the fact that they live under relatively more difficult conditions. As a result, such students might perceive attending school as an obligation to improve their living standards. Similarly, Arastaman (2009) explored that the children whose mothers have lower educational levels had higher levels of school engagement. Fullarton (2002) and Gemici and $\mathrm{Lu}$ (2014) also showed that the higher the education level of parents was; the higher students' school engagement was. As children's quality of life increases, the level of school engagement increases too (Savi, 2011).

The findings obtained in the stepwise regression analysis indicated that school engagement was predicted by students' positive attitudes towards learning at the highest level. That is to say, as students' attitudes toward learning increased, their sense of school engagement increased too. In the literature, it shows that there is a positive relationship between school engagement and desire to learn and success (Weinstein and Mayer 1986; Thomson, 2005). In a similar study, Orthner et al. (2010) found that as the value of students increases, their school engagement also increases. When students participate in off-classroom learning activities and cultural activities, their levels of school engagement increase (Shin et al., 2007). As discussed by Cernkovich and 
Giordano (1992), if students have high school responsibility, their school engagement levels are high too.

According to the research findings, being a coed or single-sex school is the second important variable that predicted school engagement. This suggests that the type of school (coed-single sex) should be taken into account in increasing the school engagement. A negative correlation was observed in the research between attending a boys' high school and a coed high school and school engagement. In other words, the boys' and coed high school students generally had lower levels of school engagement. In the research, the male students were selected from vocational high schools. It is assumed that the students attending vocational high schools had lower levels of school engagement for reasons, such as their desire to start working sooner and their unwillingness to participate in academic activities. Thompson and Ungerleider (2004) argue that male students want to participate in learning activities when these activities are more competitive, active, and appropriate to their interests; when such conditions are not provided, they become more unsuccessful in the academic field. Similarly, the school engagement levels of these students in coed schools were also low. Previous research found that girls attending single sex schools had higher achievement levels and more positive school attitudes than the students of coed schools (Bryk et al., 1993; Collins et al., 2000; Riordan, 1985; Shmurak, 1998). The present study also achieved similar results. Other studies, on the other hand, found no significant difference between the academic activities of the students attending coed and single-sex schools (Brittmon, 2008; Scoggins, 2009).

The variable that predicted school engagement in the third and fifth model is achievement level. The findings showed no negative correlation between being unsuccessful and school engagement. That is to say, the more successful the students were, the higher levels of school engagement they had. It is assumed that as the school engagement level increases, the students take more responsibilities, become happier to be at school and take part in school activities, and these positive attitudes enable them to embrace their own schools, leading to higher school engagement levels. In most of the studies, it was observed that school engagement increased academic achievement (Eith, 2005; Finn and Rock, 1997; Lee and Smith, 1995; Osterman, 2000).

The findings of this research showed that there was a negative correlation between opposite-sex attitude and school engagement. In other words, if the opposite-sex attitude was positive, the level of school engagement decreased. It should be borne in mind that the research was conducted on adolescent students. It is thought that adolescents' attitudes towards school are reduced by their increased interest in the opposite sex during this period. The typical developmental feature of this period is the increasing desire of adolescents to make friends with the opposite sex. As a result, it is assumed that the students who participated in this study had lower school engagement levels because they orientated their adolescent energy, interest, and pursuits towards the opposite sex.

It is generally expected that opposite-sex attitudes will be more positive in coed schools. Although there is no research on this subject, a study conducted by Yildırım (1998) in a coed school indicated that the students who had friends of the opposite sex had higher perceived social support. The study conducted by Dale (1969) found that the students in a coeducation environment became more socialized with the opposite sex. It is assumed that the reason why the students of coed schools had lower levels of school engagement is that opposite-sex attitudes among the coed school students are more positive than the attitudes of the singlesex school students. It is also thought that the coed school students' levels of school engagement were lower due to their desire to be together with the opposite sex in the same environment rather than being in the school in the first place. The "negative correlation between opposite-sex attitude and school engagement" which is a finding of this research coincides with these assumptions.

Lastly, the students whose fathers are primary school graduates were found to have higher school engagement levels. As seen in the multiple regression analysis conducted in the study, parents' low educational levels were observed to be a predictor of school engagement whereas the stepwise regression analysis concluded that the students whose fathers are primary school graduates were found to have higher school engagement levels. There may be many possible reasons for higher social engagement levels of the students whose parents' have low educational levels. It is thought that the students of families with lower educational and financial levels had higher levels of school engagement because they believe that the best way to escape from their disadvantageous conditions is to receive a good education and acquire a good occupation. The research carried out by Arastaman (2006) showed that the lower the parents' educational levels were, the lower school engagement levels the children had. Another study by Conchas (2001) found that the children of families with a low socio-economic level had high levels of school engagement. However, another study by Fullarton (2002) achieved a different result indicating that the children had higher levels of school engagement when their parents had higher educational and socio-economic levels. Different results achieved by studies necessitate carrying out even more research on the relationship between these two variables.

School engagement affects not only students' sense of belonging to the school, but also their academic, mental and emotional development. According to the research results, positive attitudes towards learning increased school engagement. It is therefore considered important to perform studies at schools to inform students of learning how to learn. Efforts to increase school engagement undoubtedly increase students' academic achievement. In this context, it can be recommended to organize programs that will enable school counseling services to play a more active role in increasing school engagement. The research findings showed that the girls' school students had higher levels of school engagement in their schools. Contrary to expectations, the coed school students were found to have lower levels of school engagement. Given that it is important to consider individual differences and it is attempted to regulate contents of courses accordingly in today's education systems, it is imperative to do research that take into consideration gender differences. Indeed, male and female students vary by their interests, attitudes, and behaviors. Hence, different studies on the effects of coeducation or single-sex education on student development are required. It is also considered important to establish pilot schools formed by single-sex classes and conduct research on their effects on developmental characteristics of students. The study showed that as the education level of parents increased, school engagement decreased. New research should be performed to explore the reasons and the precautions to be taken. Finally, the findings of the study should be interpreted with regard to the context where it was carried and the participants who took part in it. It is therefore important to conduct similar studies on different contexts and different sample groups.

\section{Data availability}

All data analyzed or generated are available in the paper.

Received: 22 October 2019; Accepted: 6 April 2020;

Published online: 05 May 2020 


\section{References}

Aktürk AO (2012) Öğretmen adaylarının öğrenmeye ilişkin tutumlarının öğretmenlik mesleğini tercih etme nedenlerine ve akademik başarılarına göre incelenmesi. Ahi Evran Üniversitesi Kırșehir Eğitim Fakültesi Derg 13 (3):283-237

Appleton JJ, Christenson SL, Kim D, Reschly AL (2006) Measuring cognitive and psychological engagement: Validation of the Student Engagement Instrument. J Sch Psychol 44(5):427-445

Arastaman G (2006) Ankara ili lise birinci sınıf öğrencilerinin okula bağlllık durumlarına ilişkin öğrenci, öğretmen ve yöneticilerin görüşleri (Yayınlanmamış Yüksek Lisans Tezi). Ankara Üniversitesi, Ankara

Arastaman G (2009) Lise birinci sınıf öğrencilerinin okula bağlllık durumlarına ilişkin öğrenci, öğretmen ve yöneticilerin görüşleri. Pamukkale Üniv Eğitim Fak Derg 26(26):102-112

Audas R, Willms JD (2002) Engagement and dropping out of school: a life-course perspective. Applied Research Branch, Human Resources Development, Canada

Başaranoğlu Y (2011) Üniversite öğrencilerinin cinsiyete göre psikolojik doğum sırası ile karșı cinsle ilișkide sosyal yetkinlik beklentisi düzeyleri arasındaki ilișkinin incelenmesi (Yayınlanmamış Yüksek Lisans Tezi). Çukurova Üniversitesi, Adana

Bråten I, Strømsø HI (2006) Epistemological beliefs, interest, and gender as predictors of Internet-based learning activities. Comput Hum Behav 22 (6):1027-1042

Brittmon TY (2008) Single-sex classrooms: do they impact student absenteeism, academic achievement, and the drop-out rate? Union University

Bryk AS, Lee VE, Holland PB (1993) Catholic schools and the common good. Harvard University Press, Cambridge, MA

Büyüköztürk Ş, Kılıç Çakmak E, Akgün ÖE, Karadeniz \$̧, Demirel F (2012) Örnekleme yöntemleri. Erișim 18:2019

Conchas G (2001) Structuring failure and success: understanding the variability in Latino school engagement. Harv Educ Rev 71(3):475-505

Cernkovich SA, Giordano PC (1992) School bonding, race, and delinquency. Criminology 30(2):261-291

Clinton H (2001) Karma Eğitim mi Tek Cinsiyetli Eğitim mi. http://www.aljazeera. com.tr/al-jazeera-ozel/karma-egitim-mi-tek-cinsiyetli-egitim-mi. Erişim tarihi. Accessed 12 Sept 2018

Collins AW, Sprinthall AN (1995) Adolescent psychology. McGraw, New York

Collins CW, McLeod J, Kenway J (2000) Factors influencing the educational performance of males and females in school and their initial destinations after leaving school. Department of Education, Training and Youth Affairs, Canberra

Conchas G (2001) Structuring failure and success: understanding the variability in Latino school engagement. Harv Educ Rev 71(3):475-505

Connell JP, Spencer MB, Aber JL (1994) Educational risk and resilience in African American youth: context, self, action, and outcomes in school. Child Dev 65 (2):493-506

Dale RR (1969) Mixed or single-sex school? [Vol. 1], A research study about pupilteacher relationships. Routledge \& K. Paul

Deem R (ed) (1984) Co-education reconsidered. Open University Press

Duarte AM (2007) Conceptions of learning and approaches to learning in Portuguese students. High Educ 54(6):781-794

Eith C (2005) Delinquency, schools, and the social bond. LFB Scholarly Publishing LLC, New York

Elam JH (2009) An examination of single-gender and coeducational classes: Their impact on the academic achievement of middle school students enrolled in mathematics and science at selected schools in Georgia. South Carolina State. Retrieved from http://gradworks.umi.com/34/21/3421367.html

Erdoğdu MY (2016) Analysis of students' school engagement in terms of friendship and teachers' behavior. Educ Res Rev 11(22):2057-2064

Erdoğdu MY (2017) Learning styles and variables in predicting attitude towards learning. Int J Humanit Manag Sci 5(1):2320-4044

Erdoğdu MY (2018) Karşı cinse yönelik tutum ölçeğinin geliştirilmesi. Süleyman Demirel Üniv Sos Bilim Enst Derg 2(31):200-212

Finlay KA (2006) Quantifying school engagement: research report. National Center for School Engagement, Denver

Finn JD (1993) School Engagement \& Students at Risk. National Center of Educational Statistics, Washington, DC

Finn JD, Voelkl KE (1993) School characteristics related to school engagement. J Negro Educ 62(3):249-268

Finn JD, Rock DA (1997) Academic success among students at risk for school failure. J Appl Psychol 82(2):221-234

Fredricks JA, Blumenfeld PC, Paris AH (2004) School engagement: potential of the concept, state of the evidence. Rev Educ Res 74(1):59-109

Fritz RA (1996) An inferential study comparing science achievement in single-sex and mixed-sex schools: testing for interactions between gender and instructional environment. Diss Abstr Int 57(03):1082A

Fullarton S (2002) Student engagement with school: Individual and school-level influences (LSAY Research Report No. 27). ACER, Camberwell, Australia

Garcia DM (1998) Single-sex vs. Coeducational public schooling for girls: A high school comparison study. Diss Abstr Int 59(07):2434A
Gauley J (2017) Pathways to student engagement in school: Exploring the effects of school climate on school engagement (Doctoral dissertation). The University of Wisconsin, Madison. Retrieved from http://www.proquest.com/

Gemici S, Lu T (2014) Do schools influence student engagement in the high school years? Longitudinal Surveys of Australian Youth, NCVER, Adelaide

Gibb SJ, Fergusson DM, Horwood LJ (2008) Effects of single-sex and coeducational schooling on the gender gap in educational achievement. Aust J Educ 52 (3):301-317

Hammaker JM (1995) Learning together: A history of coeducation in american schools: and New Haven \& London, Yale University Press, The Russet Sage Foundation, New York. Econ Educ Rev 14(1):98-99

Heppner PP, Wampold BE, Kivlighan DM-Jr (2013) Psikolojik danışmada araştırma yöntemleri [Research design in counseling] (DM Siyez, Trans.) Mentis Yayıncillk, Ankara, Turkey

Hergenhann BR (1988) An introduction to learning theories. Prentice-Hall, Englewood Cliffs

Hirschfield PJ, Gasper J (2011) The relationship between school engagement and delinquency in late childhood and early adolescence. J Youth Adolesc 40 (1):3-22

Hoy WK, Miskel CG (2010) Eğitim yönetimi. (Çev. Edt: S. Turan). Nobel, Ankara

Janosz M, Archambault I, Morizot J, Pagani LS (2008) School engagement trajectories and their differential predictive relations to dropout. J Soc Issues 64 (1):21-40

Kamer ST (2013) Türk eğitim sisteminde karma eğitime ilişkin fikirler, tartı̧̧malar ve uygulamalar (1908-1950). (Yayınlanmamıs Doktora Tezi). Ankara Üniversitesi Eğitim Bilimleri Enstitüsü Eğitimin Kültürel Temelleri Anabilim Dalı, Ankara

Kara A (2010) Öğrenmeye ilișkin tutum ölçeğinin geliștirilmesi. Elektron Sos Bilimler Derg 9(32):49-63

Klem AM, Connell JP (2004) Relationships matter: linking teacher support to student engagement and achievement. J Sch Health 74(7):262-273

Kohlhaas K, Lin HH, Chu KL (2010) Science equity in third grade. Elem Sch J 110 (3):393-408

Lacey RS, Reifman A, Scott JP, Harris SM, Fitzpatrick J (2004) Sexual-moral attitudes, love styles, and mate selection. J Sex Res 41(2):121-128

Lee VE, Bryk AS (1986) Effects of single-sex secondary schools on student achievement and attitudes. J Educ Psychol 78(5):381

Lee VE, Smith JB (1995) Effects of high school restructuring and size on early gains in achievement and engagement. Sociol Edu 68(4):241-270

Leonard D (2007) Single-sex and co-educational secondary schooling: Life course consequences. Economic and Social Research Centre (ESRC) Report. RES000-22-1085. ESRC, Swindon, UK

Liem GAD, Martin AJ (2011) Peer relationships and adolescents' academic and non-academic outcomes: same-sex and opposite-sex peer effects and the mediating role of school engagement. Br J Educ Psychol 81(2):183-206

Mael FA (1998) Single-sex and coeducational schooling: relationships to socioemotional and academic development. Rev Educ Res 68(2):101-129

Marsh HW (1989) Sex differences in the development of verbal and mathematics constructs: the high school and beyond study. Am Educ Res J 26(2):191-225

Marsh HW, Rowe KJ (1996) The effects of single-sex and mixed-sex mathematics classes within a coeducational school: a reanalysis and comment. Aust J Educ 40(2):147-161

McFarland B, Benson AM, McFarland M (2011) Comparing achievement scores of students in gender specific classrooms with students in traditional classrooms. Int J Psychol 8:99-114

Mc Neely C, Falci C (2004) School connectedness and transition into and out of health-risk behavior among adolescents: Acomparison of social belonging and teacher support. J Sch Health 74(7):284-292

Mengi S (2011) Ortaöğretim 10. ve 11. sinıf öğrencilerinin sosyal destek ve öz yeterlik düzeylerinin okula bağlllıkları ile ilişkisi (Yayınlanmamış Yüksek Lisans Tezi). Sakarya Üniversitesi Sosyal Bilimler Enstitüsü, Sakarya

Mulholland J, Hansen P, Kaminski E (2004) Do single-gender classrooms in coeducational settings address boys' underachievement? An Australian study. Educ Stud 30(1):19-32

Neel CGO, Fuligni A (2013) A longitudinal study of school belonging and academic motivation across high school. Child Dev 84(2):678-692

Ormrod JE (1990) Human learning: principles, theories, and educational applications. Merrill Publishing Company

Orthner DK, Akos P, Rose R, Jones-Sanpei H, Mercado M, Woolley ME (2010) CareerStart: a middle school student engagement and academic achievement program. Child Sch 32(4):223-234

Osterman FK (2000) Students'need for belonging in the school community. Rev Educ Res 17(3):323-367

Öztürk MO (1995) Ruh sağlığı ve bozuklukları. Hekimler Yayın Birliği, Ankara

Pierce R, Stacey K, Barkatsas A (2007) A scale for monitoring students' attitudes to learning mathematics with technology. Comput Educ 48(2):285-300

Prokop P, Lešková A, Kubiatko M, Diran C (2007) Slovakian students' knowledge of and attitudes towards biotechnology. Int J Sci Educ 29(7):895-907 
Riordan C (1985) Public and Catholic schooling: the effects of gender context policy. Am J Educ 93(4):518-540

Roberson AE (2010) The efficacy of single-sex education: testing for selection and school quality effects (Doctoral dissertation). The University of Texas. Faculty of the Graduate School

Rycik JA (2008) Revisiting the gender gap. Am Second Educ 36(3):98

Savi F (2011) Çocuk ve ergenler için okula bağlanma ölçeği: Geçerlik ve güvenirlik çalışması. İlköğretim Online 10(1):80-90

Schober B, Reimann R, Wagner P (2004) Is research on gender-specific underachievement in gifted girls an obsolete topic? New findings on an oftendiscussed issue. High Abil Stud 15(1):43-62

Schunk DH (2009) Öğrenme teorileri eğitimsel bir bakış. Nobel Yayın Dağıtım, Ankara

Schwartz B, Reisberg D (1991) Learning and memory. WW Norton \& Co

Scoggins DK (2009) The differences in academic achievement between single-sex education and coeducation classes in fifth grade. University of Arkansas

Shin R, Daly B, Vera E (2007) The relationships of peer norms, ethnic identity, and peer support to school engagement in urban youth. Prof Sch Couns 10(4):379-388

Shmurak CB (1998) Voices of hope: adolescent girls at single sex and coeducational schools, vol. 4. Peter Lang Pub Incorporated

Silins H, Mulford B (2002) Schools as learning organizations: The case for system, teacher and student learning. J Educ Adm 40(5):425-446

Simons-Morton BG, Crump AD (2003) Association of parental involvement and social competence with school adjustment and engagement among sixth graders. J Sch Health 73(3):121-126

Simons-Morton B, Chen R (2009) Peer and parent influences on school engagement among early adolescents. Youth Soc 41(1):3-25

Smithers A, Robinson P (2006) The paradox of single-sex and co-educational schooling. Carmichael Press, Buckingham

Spender D, Sarah E (1980) Learning to lose: sexism and education. Womens Pr Ltd

Spielhofer T, Benton T, Schagen S (2004) A study of the effects of school size and single-sex education in English schools. Res Pap Educ 19(2):133-159

Sullivan HS (1953) The interpersonal theory psychiatry. Norton, New York

Thaliah R, Hashim RA (2008) Teacher's autonomy suport and ESL classroom engagement: The road less traveled. Proceedings of the EDU-COM 2008 International Conference. Sustainability in Higher Education: Directions for Change, Edith Cowan University, Perth Western Australia. Retrieved from http://ro.ecu.edu.au/ceducom/50

Thomson S (2005) Engaging students with school life. Youth Stud Aust 24(1):10

Thom CE (2006) A comparison of the effect of single-sex versus mixed-sex classes on middle school student achievement.

Thompson T, Ungerleider C (2004) Single-sex schooling: final report. Canadian Centre for Knowledge Mobilisation, Waterloo
Türkoğlu İE, Akbaş T, Çelikkaleli Ö (2015) Üniversite öğrencilerinin cinsiyet ve flört davranıșlarına göre karșı cinsle ilișkide sosyal yetkinlik inancının incelenmesi. Çukurova Üniv Sos Bilim Enst Derg 24(2):189-198

Underwood MK, Beron KJ, Rosen LH (2009) Continuity and change in social and physical aggression from middle childhood through early adolescence. Aggress Behav 35(5):357-375

Weinstein CE, Mayer RE, Wittrock MC (1986) The teaching of Learning strategies. In: Wittrock M (ed.), The handbook of research on teaching. pp. 315-327

Yıldırım İ (1998) Akademik başarı düzeyleri farklı olan lise öğrencilerinin bazı değişkenlere göre sosyal destek düzeyleri. Türk Psikol Danışma Rehb Derg 2 (10):33-45

\section{Competing interests}

The authors declare no competing interests.

\section{Additional information}

Correspondence and requests for materials should be addressed to M.Y.E

Reprints and permission information is available at http://www.nature.com/reprints

Publisher's note Springer Nature remains neutral with regard to jurisdictional claims in published maps and institutional affiliations.

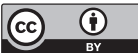

Open Access This article is licensed under a Creative Commons Attribution 4.0 International License, which permits use, sharing, adaptation, distribution and reproduction in any medium or format, as long as you give appropriate credit to the original author(s) and the source, provide a link to the Creative Commons license, and indicate if changes were made. The images or other third party material in this article are included in the article's Creative Commons license, unless indicated otherwise in a credit line to the material. If material is not included in the article's Creative Commons license and your intended use is not permitted by statutory regulation or exceeds the permitted use, you will need to obtain permission directly from the copyright holder. To view a copy of this license, visit http://creativecommons.org/ licenses/by/4.0/.

(C) The Author(s) 2020 